\title{
UJI AKTIVITAS ANTIBAKTERI EKSTRAK TERIPANG GAMAT (Stichopus Variegatus) DARI KEPULAUAN MENTAWAI TERHADAP BAKTERI STREPTOCOCCUS VIRIDANS
}

\author{
Geistia Fad'ha*, Utmi Arma*, Busman** \\ *Bagian Ilmu Penyakit Mulut FKG Universitas Baiturrahmah \\ **Bagian Oral Biologi FKG Universitas Baiturrahmah \\ Jl. Raya By. Pass KM. 14 Sei Sapih, Padang \\ Email : utmiarma@yahoo.com
}

\section{KATA KUNCI}

Aktivitas antibakteri, Stichopus variegatus, Streptococcus viridans

\section{KATA KUNCI}

Antibacterial activity, Stichopus variegatus, Streptococcus viridans

\begin{abstract}
ABSTRAK
Kabupaten Kepulauan Mentawai Provinsi Sumatera Barat mempunyai wilayah pantai yang cukup luas dan tersimpan kekayaan laut yang memiliki potensi ekonomi yang tinggi, salah satunya adalah Teripang. Teripang selain memiliki nilai gizi yang tinggi juga mempunyai aktivitas antibakteri terhadap bakteri patogen. Di bidang kedokteran gigi, Streptococcus viridans merupakan salah satu bakteri penyebab utama dalam permasalahan kesehatan gigi di rongga mulut. Bakteri ini merupakan flora normal di rongga mulut yang dapat menyebabkan karies gigi. Penelitian ini bertujuan untuk mengetahui aktivitas antibakteri ekstrak Teripang Gamat (Stichopus variegatus) dari Kepulauan Mentawai terhadap bakteri Streptococcus viridans. Penelitian ini merupakan penelitian eksperimental laboratorium menggunakan metode disc diffusion (tes Kirby \& Bauer) yang telah dilakukan pada bulan Januari-Maret 2016 di Laboratorium Biota Sumatera, Universitas Andalas. Hasil penelitian diuji menggunakan Uji ANOVA dengan tingkat signifikan 5\% dengan aplikasi SPSS for windows 16.0. Hasil penelitian diketahui rata-rata diameter zona hambat ekstrak Teripang Gamat (Stichopus variegatus) dari Kepulauan Mentawai terhadap bakteri Streptococcus viridans paling tinggi pada konsentrasi 2,5\% dengan nilai $8,45 \mathrm{~mm}$ yang termasuk kategori sedang. Nilai p-value dari hasil tes uji anova p-value $<0,05$ $(p=0,012)$. Hasil analisis varians adalah Fhitung $=4.040$ lebih besar dari Ftabel $=2,773$ berarti ada pengaruh variabel bebas terhadap variabel terikat $\mathrm{Ha}$ diterima dan Ho ditolak. Berdasarkan hasil penelitian dapat disimpulkan bahwa terdapat aktivitas antibakteri ekstrak Teripang Gamat (Stichopus variegatus) dari Kepulauan Mentawai terhadap bakteri Streptococcus viridans.
\end{abstract}


Sumatra Laboratory, Andalas University. The result analyzed by using ANOVA test with 5\% significant level, SPSS for windows 16.0 application. The result showed that the average diameter of inhibition zone of TeripangGamat extract from Mentawai islands towards Streptococcus viridans was at $2.5 \%$ concentration with $8.45 \mathrm{~mm}$ value that included as medium category. P-value from ANOVA test $<0.05$ $(p=0.012)$. The result from variant analysis id $f$ count $=4.040$ more than $f$ table $=2.773$ means that there was effect of independent variable toward dependent variable Ha was accepted and Ho was declined. Based on the result, can be concluded that there was antibacterial activity of TeripangGamat extract (Stichopus variegatus) from Mentawai islands towards Streptococcus viridians.

\section{PENDAHULUAN}

Indonesia adalah negara kepulauan yang memiliki luas daratan 1,9 juta $\mathrm{km}^{2}$ yang di pisahkan oleh selat dan laut. Menurut letaknya, Indonesia merupakan salah satu kawasan paling startegis di dunia yang beradadi segitiga Indo-Pasifik Barat dengan iklim tropis. Perairan di Indonesia yang mempunyai wilayah pantai yang cukup luas salah satunya adalah Kabupaten Kepulauan Mentawai Provinsi Sumatera Barat. Sepanjang perairan pantai tersimpan kekayaan yang memiliki potensi perikanan yang cukup besar dan memiliki potensi ekonomi yang tinggi, salah satunya adalah Teripang ${ }^{1,2}$. Teripang mempunyai kandungan atau kadar nutrisi yang banyak sehingga memiliki nilai ekonomi yang tinggi. Jumlah spesies yang ada di seluruh dunia sekitar 1.135 spesies. Indonesia memiliki $10 \%$ dari jenis spesies tersebut atau mencapai 257 spesies namun baru 60 spesies yang teridentifikasi. Beberapa jenis spesies tersebut, hanya 5 spesies yang banyak dicari karena memiliki nilai ekonomi dan nilai gizi yang cukup tinggi. Di Kepulauan Mentawai
Kecamatan Sikabaluan jenis spesies Teripang yang banyak ditemukan adalah Stichopus variegatus, Holothuria scabra, Holothuria marmorata dan Thelenota ananas. Di Indonesia Teripang dimanfaatkan sebagai bahan makanan, terutama oleh masyarakat disekitar pantai ${ }^{1,3,4}$.

Teripang memiliki potensi untuk dikembangkan sebagai bahan antibakteri terhadap bakteri patogen. Pemanfaatan sebagai sumber bahan antibakteri dapat memberikan nilai yang cukup tinggi. Hasil penelitian Ridwan Hashim, menemukan bahwa teripang memiliki efek antibakteri terhadap Streptococcus faecalis, Streptococcus viridans, Streptococcus pneumonia dan Staphylococcus aureus. Dari hasil percobaan yang dilakukan terlihat bahwa terhambatnya pertumbuhan bakteri setelah diberi ekstrak teripang spesies Holothuria atra, Holothuria scabra dan Bohadshi argus ${ }^{1,3,5}$. Hasil penelitian Farouk dkk (2007), menunjukkan bahwa metabolit sekunder dalam Teripang yang berpotensi sebagai senyawa antibakteri adalah golongan senyawa terpenoid, diantaranya saponin, 
steroid dan triterpenoid. Golongan senyawa tersebut beberapa polisakarida yang dapat menembus membran sel bakteri sehingga menyebabkan kerusakan sel bakteri ${ }^{6}$.

Di bidang kedokteran gigi, Streptococcus mutans merupakan salah satu bakteri penyebab utama dalam permasalahan kesehatan gigi di rongga mulut. Streptococcus mutans merupakan bakteri dari kelompok Streptococcus viridians yang memiliki sifat $\alpha$-hemolitik. Bakteri ini merupakan flora normal paling kariogenik di rongga mulut yang dapat menyebabkan karies gigi atau gigi berlubang. Prevalensi karies gigi pada negara maju terus menurun, sedangkan di negara-negara berkembang termasuk Indonesia ada kecenderungan meningkat. Data menunjukkan sekitar $80 \%$ penduduk Indonesia memiliki gigi berlubang yang disebabkan berbagai faktor. Hampir setiap mulut orang Indonesia akan ditemukan dua hingga tiga gigi berlubang. Persentase penduduk yang mempunyai masalah gigi dan mulut menurut Riskesdas tahun 2007 dan 2013 meningkat dari $23,2 \%$ menjadi $25,9 \%{ }^{7}$, 8,9 .

Hasil penelitian atau laporan tentang aktivitas antibakteri ekstrak Teripang Gamat (Stichopus variegatus) dari Kepulauan Mentawai terhadap bakteri Streptococcus viridans sampai saat ini belum ada. Oleh karena itu, berdasarkan uraian diatas penulis tertarik melakukan penelitian ini untuk menguji aktivitas antibakteri ekstrak Teripang Gamat (Stichopus variegatus) dari
Kepulauan Mentawai terhadap bakteri Streptococcus viridans.

\section{METODE}

Jenis penelitian ini adalah penelitian eksperimental laboratorium. Percobaan ini menggunakan metode disc diffusion (tes Kirby \& Bauer). Teripang Gamat (Stichopus variegatus) yang diambil dari Kepulauan Mentawai diambil secara acak dengan menelusuri sekitar kedalaman 3-4 m di bawah laut selanjutnya dilakukan identifikasi toksonomi di Laboratorium Ekologi Hewan Jurusan Biologi FMIPA, Universitas Andalas. Ekstraksi dan uji aktivitas antibakteri dilakukan pada bulan JanuariMaret 2016 di Laboratorium Biota Sumatera, Universitas Andalas.

Alat

Gunting, kertas saring, botol gelap 2,5 liter, tabung reaksi, tabung Erlenmeyer $250 \mathrm{ml}$, Rotary Evaporator Buci R-210, destilasi, kertas saring Whatman, labu Rotary $2000 \mathrm{ml}$, spektrometer, corong, timbangan digital, petridish, spatel, pipet mikro, jarum ose, cotton bud, benang jagung, kertas koran, lampu spiritus, jangka sorong, autoclave, hot plate, pinset, kasa dan kapas steril.

\section{Bahan}

Bahan utama yang digunakan adalah Teripang Gamat (Stichopus Variegatus), bakteri Streptococcus viridans, etanol 96\%, alkohol 70\%, Nutrien agar, larutan fisiologis $\mathrm{NaCl} \quad 0,9 \%, \quad$ Chlorhexidine dan $\mathrm{DMSO}$ (dimetil sulfoksid). 
Fad'ha : Uji aktivitas antibakteri ekstrak teripang gamat...

\section{Sterilisasi Alat}

Alat yang akan digunakan untuk pengujian dicuci bersih dan dikeringkan. Tabung reaksi dan erlenmeyer ditutup mulutnya dengan kasa yang diisi kapas. Kemudian petridish, tabung reaksi, erlenmeyer, kertas cakram dan cotton bud dibungkus dengan kertas koran dan disterilkan di dalam autoclave dengan tekanan $1 \mathrm{~atm}$ dan suhu $121^{\circ} \mathrm{C}$ selama lebih kurang 15 menit. Jarum ose dan pinset disterilkan dengan cara flambier pada lampu spiritus. Laminar Air Flow cabinet sebelum digunakan dibersihkan menggunakan Alkohol 70\%, kemudian disterilkan dengan menyalakan lampu UV selama 10 menit ${ }^{10}$.

\section{Maserasi dan Pembuatan Ekstrak}

\section{Teripang Gamat}

Hasil maserasi Teripang Gamat yang pertama disaring menggunakan kertas saring Whatman dan dimasukkan kedalam botol coklat pertama. Teripang Gamat dipotong kecil dengan ukuran lebih kurang 2-4 cm menggunakan gunting untuk mempercepat proses maserasi Teripang Gamat. Setelah itu, hasil potongan Teripang Gamat dimasukkan kedalam botol coklat kedua dan di maserasi kembali dengan etanol 96\% selama $3 \times 24$ jam. Kemudian hasil maserasi Teripang Gamat yang diperoleh disaring dan dimasukkan kedalam botol coklat pertama. Perlakuan ini di lakukan sabanyak 4 kali maserasi. Setelah hasil maserasi diperoleh, dilakukan destilasi untuk mengurangi jumlah zat pelarut etanol $96 \%$ dari hasil maserasi. Kemudian hasil destilasi dilakukan rotary menggunakan rotary evaporator Buci R-210 sehingga diperoleh maserat pekat dari Teripang Gamat.

\section{Pembuatan Konsentrasi Ekstrak Teripang}

\section{Gamat}

Konsentrasi ekstrak Teripang yang digunakan dalam penelitian ini adalah $20 \%$; $10 \% ; 5 \% ; 2,5 \% ; 1,25 \%$ dan $0,625 \%$. Bahan yang digunakan sebagai pelarut ekstrak teripang Gamat (Stichopus Variegatus) adalah larutan DMSO.

Tabel 1. Konsentrasi Larutan Ekstrak Teripang Gamat (Stichopus Variegatus)

\begin{tabular}{ccc}
\hline $\begin{array}{c}\text { Ekstrak Teripang } \\
\text { Gamat (gr) }\end{array}$ & Volume akhir (ml) & $\begin{array}{c}\text { Konsentrasi } \\
(\%)\end{array}$ \\
\hline 4 & 20 & $20 \%$ \\
\hline 2 & 20 & $10 \%$ \\
\hline 1 & 20 & $5 \%$ \\
\hline 0,5 & 20 & $2,5 \%$ \\
\hline 0,25 & 20 & $1,25 \%$ \\
\hline 0,125 & 20 & $0,625 \%$ \\
\hline
\end{tabular}

\section{Pembuatan Media Nutrient Agar}

Masukkan 20 gram serbuk nutrient agar (NA) kedalam labu Erlenmeyer kemudian larutkan dengan aquades sebanyak $1000 \mathrm{ml}$, setelah itu panaskan dan diaduk hingga larut di atas hotplate. Setelah itu bungkus dengan kertas koran lalu disterilkan dengan autoclave pada suhu $121^{\circ} \mathrm{C}$ selama 15 menit.

\section{Pembuatan Suspensi Bakteri Uji}

Bakteri ditanam pada media pertumbuhan nutrient agar (NA) miring dalam tabung reaksi dan di inkubasi pada suhu $37^{\circ} \mathrm{C}$ selama 1 x 24 jam, kemudian bakteri yang akan diuji di suspensikan dengan cara menumbuhkan bakteri dalam media cair 
yaitu larutan fisiologis $\mathrm{NaCl}$ 0,9\% sampai diperoleh kekeruhan sesuai standar 0,5 Mc Farland atau sebanding dengan jumlah bakteri $1 \times 10^{8} \mathrm{CFU} / \mathrm{ml}$.

\section{Uji Aktivitas Antibakteri}

Uji aktivitas antibakteri yang dilakukan pada percobaan ini menggunakan metode difusi. Metode ini melihat area jernih pada media agar yang mengindikasikan adanya hambatan pertumbuhan mikroorganisme oleh agen antimikroba pada permukaan media agar ${ }^{12}$.

Suspensi mikroba uji diusapkan secara merata pada media nutrient agar dengan menggunakan cotton bud. Bagian bawah petridish sebelumnya ditempelkan kertas label yang telah dituliskan sesuai konsentrasi ekstrak. Kemudian ambil kertas cakram dan teteskan cairan konsentrasi menggunakan pipet mikro, lalu di letakkan pada media nutrient agar. Setelah itu bungkus petridish dengan plastic wrap, kemudian diinkubasi pada suhu $37^{\circ} \mathrm{C}$ selama 1 x 24 jam di incubator. Setelah 24 jam diamati pertumbuhan mikroba uji dan diukur diameter zona hambat. Pengukuran zona hambat diukur dengan melihat zona bening lalu diukur diameternya dengan jangka sorong.

Data yang diperoleh dianalisis secara statistk dengan Uji ANOVA dengan tingkat signifikasi 5\% dengan menggunakan aplikasi SPSS for windows $16 .{ }^{11}$

\section{HASIL}

Aktivitas antibakteri dipengaruhi oleh beberapa faktor antara lain konsentrasi ekstrak, kandungan senyawa antibakteri, daya difusi ekstrak dan jenis bakteri ${ }^{12}$.

Tabel 1. Konsentrasi ekstrak teripang gamat

\begin{tabular}{ccccccccc}
\hline \multirow{2}{*}{ Pengulangan } & \multicolumn{9}{c}{ Konsentrasi } & \multirow{2}{*}{ Kontrol } & \multirow{2}{*}{ Kontrol } \\
\cline { 2 - 9 } & $\mathbf{0 , 6 2 5 \%}$ & $\mathbf{1 , 2 5 \%}$ & $\mathbf{2 , 5 \%}$ & $\mathbf{5 \%}$ & $\mathbf{1 0 \%}$ & $\mathbf{2 0 \%}$ & - & + \\
\hline I & 9,2 & 8,7 & 9,4 & 6,2 & 7,7 & 6,2 & 10,8 & 0,0 \\
\hline II & 8,7 & 7,8 & 8,4 & 8,5 & 6,3 & 6,5 & & \\
\hline III & 7,5 & 8,1 & 7,5 & 8,3 & 7,6 & 6,8 & & \\
\hline IV & 7,3 & 7,6 & 8,5 & 7,5 & 7,5 & 6,1 & & \\
\hline Rata-Rata & $\mathbf{8 , 1 7}$ & $\mathbf{8 , 0 5}$ & $\mathbf{8 , 4 5}$ & $\mathbf{7 , 6 3}$ & $\mathbf{7 , 2 7}$ & $\mathbf{6 , 4}$ & & \\
\hline
\end{tabular}

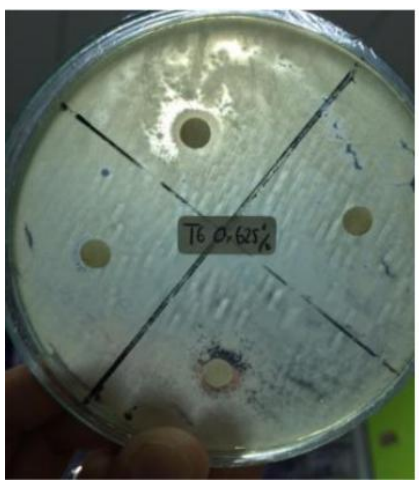

Gambar 1. Konsentrasi 0,625\%

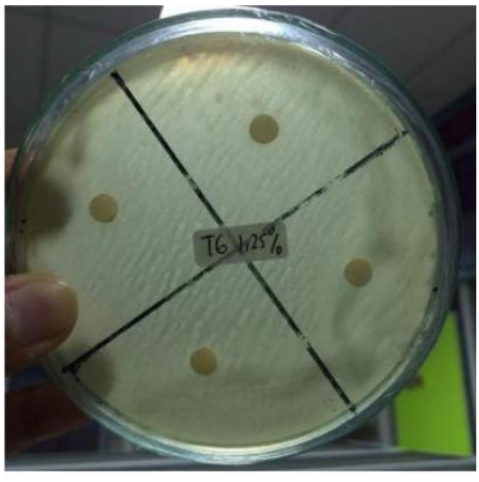

Gambar 2. Konsentrasi 1,25\%

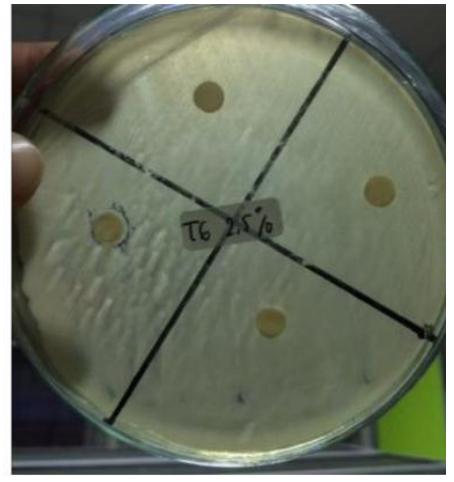

Gambar 3. Konsentrasi 2,5\% 


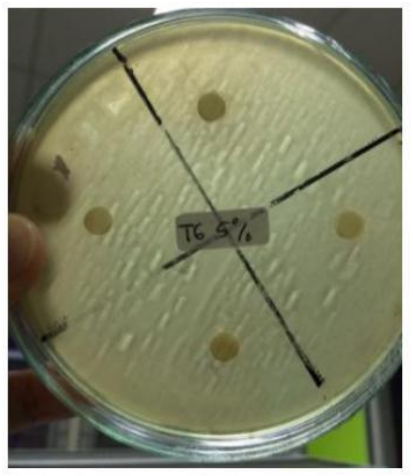

Gambar 4. Konsentrasi 5\%

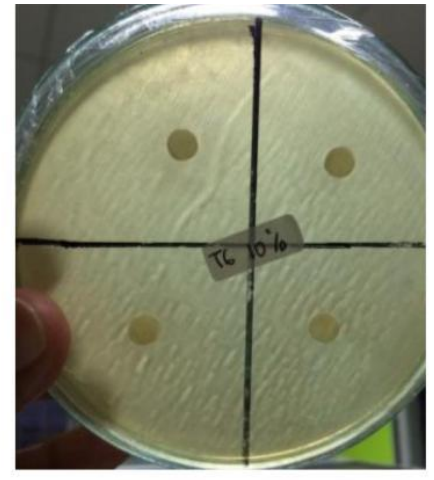

Gambar 5. Konsentrasi 10\%

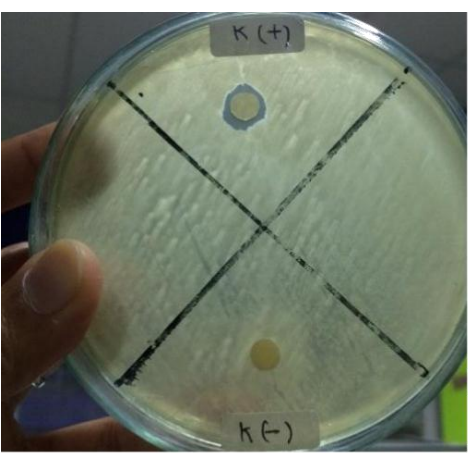

Gambar 7. Kontrol + dan Kontrol -

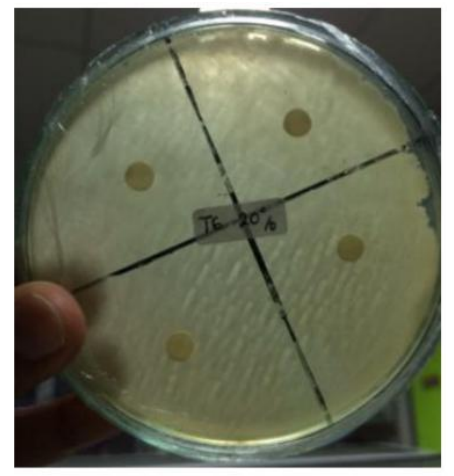

Gambar 6. Konsentrasi 20\%
Berdasarkan tabel hasil diketahui bahwa hasil rata-rata diameter zona hambat ekstrak Teripang Gamat (Stichopus variegatus) dari Kepulauan Mentawai terhadap bakteri Streptococcus viridans paling tinggi pada konsentrasi $2,5 \%$ dengan nilai $8,45 \mathrm{~mm}$ kategori sedang menurut ${ }^{13}$. Konsentrasi 2,5\% merupakan konsentrasi maksimum yang dapat menghambat pertumbuhan bakteri Streptococcus viridans. Sedangkan, pada konsentrasi 5\%, 10\% dan 20\% mengalami penurunan diameter zona hambat terhadap bakteri Streptococcus viridans.

Penurunan diameter zona hambat dikarenakan bakteri dapat menjadi sensitif atau resisten terhadap antibakterial tertentu. Jika suatu bakteri sensitif terhadap suatu obat, maka organisme bakteri akan tetap tumbuh meskipun telah dilakukan pemberian obat. Hal ini menunjukkan penggunaan antibakteri melebihi ambang batas (over dosis), akan menyebabkan bakteri menjadi kebal terhadap antibakteri. Selain itu, penurunan diameter zona hambat bisa disebabkan karena ekstrak tidak mampu berdifusi. Konsentrasi ekstrak yang terlalu pekat membuat ekstrak tidak mampu berdifusi dengan maksimal.

Konsentrasi ekstrak yang tinggi menyebabkan zat-zat aktif dalam ekstrak tidak dapat larut dengan sempurna karena terjadinya kejenuhan pada ekstrak ${ }^{14,15,16}$. Hasil penelitian menunjukkan ekstrak Teripang Gamat (Stichopus variegatus) dari 
Kepulauan Mentawai terhadap pertumbuhan bakteri Streptococcus viridans dengan konsentrasi 20\%, 10\%, 5\%, 2,5\%, 1,25\% dan $0,625 \%$ sudah dalam kategori sedang. Kontrol (+) pada penelitian ini menggunakan Chlorhexidine, rata-rata diameter zona hambat Chlorhexidine terhadap pertumbuhan bakteri Streptococcus viridans tergolong ke dalam kategori kuat yaitu 10,8 mm.

Menurut Maleki dkk (2008) ${ }^{15}$ konsentrasi ekstrak terlalu pekat menyebabkan ekstrak sulit berdifusi secara maksimal ke dalam medium yang mengandung inokulum. Hal ini karena konsentrasi ekstrak yang lebih tinggi dapat terjadi kejenuhan sehingga menyebabkan senyawa-senyawa aktif yang terkandung di dalam ekstrak tidak terlarut dengan sempurna.

Aktifitas ekstrak Teripang Gamat (Stichopus variegatus) dari Kepulauan Mentawai terhadap pertumbuhan bakteri Streptococcus viridans sudah dalam kategori sedang pada percobaan pertama dengan konsentrasi terendah dalam penelitian ini $(0,625 \%)$ yaitu $9,2 \mathrm{~mm}$. Kontrol (+) pada penelitian ini menggunakan Chlorhexidine, rata-rata diameter zona hambat Chlorhexidine terhadap pertumbuhan bakteri Streptococcus viridans tergolong ke dalam kategori kuat yaitu $10,8 \mathrm{~mm}$.

Hasil penelitian ini sejalan dengan penelitian Ridwan Hashim yang menemukan bahwa Teripang memiliki efek antibakteri terhadap Streptococcus faecalis, Streptococcus viridans, Streptococcus pneumonia dan
Staphylococcus aureus. Dari hasil percobaan yang dilakukan terlihat bahwa terhambatnya pertumbuhan bakteri setelah diberi ekstrak Teripang spesies Holothuria atra, Holothuria scabra dan Bohadshi argus 1,2,5.

Hasil penelitian Farouk dkk (2007), menunjukkan bahwa metabolit sekunder yang terdapat di dalam Teripang berpotensi sebagai senyawa antibakteri ${ }^{6}$. Mekanisme kerja antibakteri adalah menghambat biosintesis dinding sel, meningkatkan permeabilitas membran sel dan mengganggu sintesis protein sel, sehingga menghambat pertumbuhan atau menyebabkan kematian sel bakteri. Antibakteri yang mempengaruhi pembentukan dinding sel atau permeabilitas membran sel bekerja sebagai bakteriosida, sedangkan yang mempengaruhi sintesis protein bekerja sebagai bakteriostatik ${ }^{17}$.

Senyawa metabolit sekunder yang terdapat pada Teripang Gamat salah satunya adalah saponin atau triterpene glycoside. Saponin memiliki aktivitas sebagai antibakteri. Saponin merupakan golongan senyawa metabolit sekunder yang dapat menghambat atau membunuh mikroba dengan cara berinteraksi dengan membran sterol. Saponin tergolong senyawa yang bekerja sebagai bakteriostatik terhadap bakteri karena memiliki kemampuan dalam menekan pertumbuhan sel bakteri. Mekanisme kerja saponin termasuk dalam kelompok antibakteri yang mengganggu permeabilitas membran sel bakteri, yang berada langsung dibawah dinding sel. Sehingga kerja saponin 
yang merusak permeabilitas membran sel menjadi sulit karena dinding sel juga tidak mudah untuk dirusak ${ }^{18,12}$.

\section{SIMPULAN}

Berdasarkan hasil penelitian maka dapat disimpulkan bahwa ekstrak Teripang Gamat (Stichopus variegatus) dari Kepulauan Mentawai terhadap bakteri Streptococcus viridans memiliki aktivitas antibakteri pada kategori sedang. Konsentrasi 2,5\% merupakan konsentrasi maksimum yang dapat menghambat pertumbuhan bakteri Streptococcus viridans. Maka dapat disimpulkan bahwa terdapat aktivitas antibakteri ekstrak Teripang Gamat (Stichopus Variegatus) dari Kepulauan Mentawai terhadap bakteri Streptococcus viridans.

\section{DAFTAR PUSTAKA}

1. Martoyo, J, NugrohoAji dan Tjahyo Winanto. 1994. Budi Daya Tripang. Penebar Swadaya. Jakarta: Penebar Swaday

2. Iswanto. 2007. Potensi Laut dan Samudra Kita. Bandung: PT Intan Sejati.

3. Kordi, M. G H. 2010. A to Z Budi Daya Biota Akuatik untuk Pangan, Kosmetik, dan obatobatan (Ed 1). Yogyakarta: Lily Publisher.

4. Elfidasari, D, Nita Noriko, Ninditasya Wulandari, Analekta Tiara Perdana. 2012. "Identifikasi Jenis Teripang Genus Holothuria Asal Perairan Sekitar Kepulauan Seribu Berdasarkan Perbedaan Morfologi”. Jurnal Al-Azhar Indonesia Seri Sains Dan Teknologi, Vol. 1, No. 3.

5. Rasyid, A. 2012. "Identifikasi Senyawa Metabolit Sekunder Serta Uji Aktivitas Antibakteri Dan Antioksidan Ekstrak Metanol Teripang Stichopus Hermanii". Jurnal Ilmu dan Teknologi Kelautan Tropis, Vol. 4, No. 2

6. Nimah, S, Widodo Farid Ma'ruf, Agus Trianto. 2012. "Uji Bioaktivitas Ekstrak
Teripang Pasir (Holothuria Scabra) Terhadap Bakteri Pseudomonas Aeruginosa Dan Bacillus Cereus". Jurnal Perikanan, Volume 1, Nomor 2.

7. Samaranayake, L. 2006. Essential Microbiology For Dentistry 3rd Edition. USA: Churchill Livingstone Elsevier.

8. Kawuryan, Uji. 2008. Hubungan Pengetahuan Tentang Kesehatan Gigi Dan Mulut Dengan Kejadian Karies Gigi Anak Sdn Kleco II Kelas V Dan VI Kecamatan Laweyansurakarta. [Skripsi]. Surakarta: Fakultas Ilmu Kesehatan Universitas Muhammadiyah Surakarta. Accessed on Jan 10th, 2015. Available on: http://etd.eprints.ums.ac.id/897/1/J21004 0006.pdf.

9. Kementrian Kesehatan, RI. 2014. Situs Kesehatan Gigi dan Mulut. Jakarta: Pusat Data dan Informasi Kementrian Kesehatan RI.

10. Busman dan Firiyasti Betty. 2011. "Uji Aktivitas Antibakteri dan Fitokimia Tanaman Obat Luka (Cestrum elegans) (Solanaceae)". Jurnal Penelitian dan Kajian Ilmiah. Menara Ilmu. Vol. V No. 25 ISSN 1693-2617.

11. Priyatno, D. 2010. Teknik Mudah dan Cepat Melakukan Analisis Data Penelitian dengan SPSS dan Tanya Jawab Ujian Pendadaran Gaya Media, Yogyakarta

12. Sari, Intan Permata, M. Agus Wibowo, Savante Arreneuz. 2015. "Aktivitas Antibakteri Ekstrak Teripang Butoh Keling (Holothuria leucospilota) dari Pulau Lemukutan Terhadap Bekteri Propionibacterium acnes dan Staphylococcus epidermis". Jurnal Program Studi Kimia, Fakultas MIPA, Universitas Tanjungpura.

13. Davis \& Stout. 1971. "Disc Plate Method Of Microbiological Antibiotic Essay". Journal Of Microbiology. Vol 22 No 4.

14. Kee, Joyce dan Evelyn R H. 1996. Farmakologi: Pendekatan Proses Keperawatan. Jakarta: EGC

15. Maleki, S, Seyyednejad S.M, Damabi M.N, dan Motamedi H. 2008. "Antibacterial Activity Of The Fruits Of Irianian Torilis Leptophylla Againts Some Clinical Pathogens". Pakistan Journal of Biological Sciences, Vol 11(9).

16. Saraswati, Dian. 2011. "Pengaruh Konsentrasi Ekstrak Daun Sirih Terhadap Daya Hambat Escherichia Coli'. Jurnal Health \& Sport Volume 3, No. 2.

17. Nikham dan Taty EB. 2012. "Uji Bahan Baku Antibakteri Dari Buah Mahkota Dewa (Phaloria Macrocarva (Scheff) Boerl). Hasil 
Iradiasi Gamma dan Antibiotik Terhadap Bakteri Pathogen". Prosiding Pertemuan Ilmiah Ilmu Pengetahuan dan Teknologi Bahan.

18. Zahro, Latifatuz dan Rudiana Agustini. 2013. "Uji Efektivitas Antibakteri Ekstrak Kasar Saponin Jamur Tiram Putih
(Pleurotus Ostreatus) Terhadap Staphylococcus Aureus Dan Escherichia Coli". UNESA Journal of Chemistry Vol.2 No. 3. Surabaya: Department of Chemistry, Faculty of Mathematics and Natural sciences. 